\title{
PERFORMANCE OF SOME FENUGREEK GENOTYPES IN SUBHUMID SUBTROPICAL RED LATERITIC BELT OF EASTERN INDIA
}

\author{
PC Kole ${ }^{1 *}$, T Goswami $^{1}$ and B Duary ${ }^{2}$ \\ ${ }^{1}$ Department of Genetics \& Plant Breeding, ${ }^{2}$ Department of Agronomy, Institute of Agriculture, Visva-Bharati \\ University, Sriniketan- 731 236, West Bengal, India
}

Accepted: $24^{\text {th }}$ February 2014

\begin{abstract}
Thirty genotypes of fenugreek were grown during winter seasons of 2009-10 and 2010-11 in subhumid subtropical red lateritic belt of Eastern India. The performance of the genotypes was assessed for eight agronomic characters, viz. plant height, days to flowering, branches per plant, pods per plant, pod length, seeds per pod, test weight and seed yield per plant. Analysis of variance pooled over the seasons revealed that the mean squares due to seasons for all the characters except branch number were highly significant indicating considerable differences between the test seasons. The mean squares due to genotypes for all the above characters were highly significant which indicated presence of variation among the genotypes. The significant mean squares due to genotype $\times$ season interaction for all the above characters indicated differential performance of the genotypes with the change in growing conditions. The variability was highest in seed yield per plant followed by pods per plant, branches per plant and seeds per pod. On the basis of performance of the genotypes for important characters including yield, the genotypes JF-14, JF-15, JF-17 and JF-21 could be considered for cultivation as seed spice of fenugreek in subhumid subtropical red lateritic belt of eastern India.
\end{abstract}

Key words: Fenugreek, Genotypic performance, Seed spice, Quantitative characters

\section{INTRODUCTION}

Fenugreek (Trigonella foenum-graecum L.), commonly known as 'methi', is native to South -east Europe and West Asia. It is now cultivated in India, Argentina, Egypt and Mediterranean countries like Southern France, Morocco, Algeria, Ethiopia and Lebanon. It has been considered to be the third important seed spice in India. Fenugreek seeds are exported from India to different foreign countries. The major international markets for fenugreek seeds are Saudi Arabia, Japan, Srilanka, Korea and the United Kingdom.

In different part of the world, seeds and young seedlings of fenugreek are often used as curries, dyes, medicines and as a vegetable (Rajagopalan, 1998; Rajagopalan, 2001; Sharma, 1990; Al-Habori and Raman, 2002; Basch et al. 2003; Acharya et al. 2006). Fenugreek can be a very useful annual legume crop for incorporation into short-term rotation (Moyer et al. 2003), for hay and silage (livestock) making and for fixation of atmospheric nitrogen into soils.

In India, the productivity of fenugreek is very low (about $1225 \mathrm{Kg} / \mathrm{ha}$ ) in comparison to other fenugreek growing countries. Unavailability of suitable high yielding varieties for various agro -climatic regions, cultivation in the marginal lands, poor crop husbandry, and inadequate plant protection measures are the main reasons behind the low productivity. Cultivation of fenugreek in subhumid subtropical red lateritic belt of West Bengal, a province in eastern part of India, is limited and systematic research on the possibility of commercial cultivation of this crop in this region is very scanty. Therefore, the present investigation was undertaken to study the agronomic performance of 30 genotypes of fenugreek grown under subhumid subtropical red lateritic belt of West Bengal.

\section{MATERIALS AND METHODS}

The experimental materials comprised 30 di-

*Corresponding author: pckole@gmail.com 
verse genotypes of fenugreek, collected from different parts of India. The genotypes of UM series and Rmt-1 were collected from All India Coordinated Spices Improvement Project, SKN College of Agriculture, Jobner, Rajasthan. The genotypes of JF series and GJ-1 were collected form Main Spices Research Station, Jagudan, Gujarat, whereas Sonali was collected from Hissar, Harayana, and IC series were obtained from National Bureau of Plant Genetic Resources (NBPGR), New Delhi. Punjab-6 was collected from Vinayak Seeds, Kanpur, and Kalmi was collected from a market in Varanasi, Uttar Pradesh. The genotypes were grown during winter season for two consecutive years 2009-2010 and 2010-2011 at the Agricultural Farm of Institute of Agriculture $\left(23^{\circ} 39^{\prime} \mathrm{N}\right.$ latitude and $87^{\circ} 42^{\prime} \mathrm{E}$ longitude with an average altitude of 58.9 metres above mean sea level), Visva-Bharati University, West Bengal. The farm is situated under sub-humid, subtropical,

\section{RESULTS AND DISCUSSION}

Analysis of variance pooled over the seasons (Table 1) revealed that the mean sums of squares due to seasons for all the above characters except branch number were highly significant indicating considerable differences between the test seasons. The mean sums of squares due to genotypes for all the above characters were highly significant which indicated presence of variation among the genotypes. The significant mean sums of squares due to genotype $\times$ season interaction for all the above characters indicated differential performance of the genotypes with the change in growing conditions. Significant genotype $x$ environment interactions in fenugreek for plant height, pod length, pods per plant and seed yield at Mandor, Rajasthan, India (Sharma et al. 1995), days to flowering, plant height, pods per plant, seeds per pod and seed yield per plant at Udaipur, Rajasthan, India (Mathur et al. 1998)

Table 1: Analysis of variance for eight quantitative characters in fenugreek

\begin{tabular}{|c|c|c|c|c|c|c|c|c|c|}
\hline \multirow[b]{2}{*}{ Source } & \multirow{2}{*}{$\mathrm{df}$} & \multicolumn{8}{|c|}{ Mean sum of Square } \\
\hline & & $\begin{array}{c}\text { Plant } \\
\text { height }\end{array}$ & $\begin{array}{l}\text { Days to flow- } \\
\text { ering }\end{array}$ & $\begin{array}{l}\text { Branch } \\
\text { number }\end{array}$ & $\begin{array}{l}\text { Pod num- } \\
\text { ber }\end{array}$ & $\begin{array}{c}\text { Pod } \\
\text { length }\end{array}$ & $\begin{array}{c}\text { Seeds } \\
\text { per pod }\end{array}$ & $\begin{array}{c}\text { Test } \\
\text { weight }\end{array}$ & $\begin{array}{r}\text { Seed yield } \\
\text { per plant }\end{array}$ \\
\hline Season $(\mathbf{S})$ & & $5021.37^{* * *}$ & $2318.43^{* *}$ & 0.24 & $1775.96^{* *}$ & $10.27^{* * F}$ & $38.36^{* *}$ & $60.32^{* *}$ & $55.70^{* *}$ \\
\hline Replication (R) & 2 & 28.59 & 6.09 & 1.35 & 5.73 & 0.71 & 3.63 & 2.13 & 0.53 \\
\hline $\mathbf{S} \times \mathbf{R}$ & 2 & 18.94 & 0.53 & 0.43 & 13.21 & 0.25 & 0.14 & 0.21 & 0.28 \\
\hline Genotype (G) & 29 & $155.53^{* *}$ & $200.19^{* *}$ & $28.64^{* *}$ & $169.21^{* *}$ & $2.10^{\text {** }}$ & $9.92^{* *}$ & $11.70^{* *}$ & $1.23^{* *}$ \\
\hline $\mathbf{G} \times \mathbf{S}$ & 29 & $40.54^{* *}$ & $27.23^{* *}$ & $4.54^{* *}$ & $78.24^{* *}$ & $0.86^{* *}$ & $5.04^{* *}$ & $1.67^{* *}$ & $0.94^{* *}$ \\
\hline Error & 116 & 12.71 & 1.96 & 0.91 & 19.60 & 0.32 & 1.87 & 0.64 & 0.168 \\
\hline
\end{tabular}

${ }^{*}{ }^{* *}$ : Significant at $\mathrm{P}=0.05$ and 0.01 , respectively.

lateritic belt of West Bengal, a province in eastern part of India. In each season, the date of sowing was $1^{\text {st }}$ week of November with a spacing of $25 \times 7.5 \mathrm{~cm}$., fertilizer dose of 30:60:60 $(\mathrm{N}: \mathrm{P}: \mathrm{K}) \mathrm{kg} \mathrm{ha}^{-1}$ and need based crop management practices like proper time of thinning, weeding, hoeing, irrigation etc. were adopted. The genotypes were grown in a randomized block design with 3 replications. Each plot consisted of 6 rows of 3-meter length. Data were recorded on 5 randomly selected plants from middle rows for eight agronomic characters, viz. plant height, days to flowering, branches per plant, pods per plant, pod length, seeds per pod, test weight and seed yield per plant. Data were subjected to statistical analysis following standard procedure. and pods per plant, seeds per pod, test weight and seed yield per plant at Sriniketan, West Bengal, India (Kole, 2005) have been reported earlier.

The mean performance of 30 genotypes for eight agronomic characters (Table 2) was as follows:

Plant height: Plant height varied from 32.67 to $52.63 \mathrm{~cm}$ with a grand mean of $40.63 \mathrm{~cm}$. The tallest genotype was JF -17 and shortest genotype was Sonali. In general, JF series had taller plant height. 
Days to flowering: Variation due to days to flowering was 52.33-74.50 days. The earliest flowering genotype was JF-22 whereas IC143875 was the last flowering genotype. The grand mean value for this character was 57.44 days. The IC genotypes were very late flowering, which may render them misfitting in mul- types could be considered for use as vegetables and/or fodder.

Pods per plant: The range of variability observed for this character was 14.83 to 32.87 with a mean value of 23.04. Among the genotypes, UM-128 was the lowest pod bearer

Table 2: Mean performance of thirty genotypes for eight quantitative characters in fenugreek

\begin{tabular}{|c|c|c|c|c|c|c|c|c|}
\hline Genotypes & $\begin{array}{l}\text { Plant height } \\
\text { (cm) }\end{array}$ & $\begin{array}{l}\text { Days to } \\
\text { flowering }\end{array}$ & $\begin{array}{l}\text { Branch } \\
\text { number }\end{array}$ & $\begin{array}{l}\text { Pod num- } \\
\text { ber }\end{array}$ & $\begin{array}{l}\text { Pod length } \\
\text { (cm) }\end{array}$ & $\begin{array}{c}\text { Seeds per } \\
\text { pod }\end{array}$ & $\begin{array}{c}\text { Test weight } \\
\text { (g) }\end{array}$ & $\begin{array}{l}\text { Seed yield } \\
\text { plant }^{-1}(\mathrm{~g})\end{array}$ \\
\hline GJ-1 & 43.00 & 54.33 & 4.42 & 21.18 & 8.42 & 10.65 & 11.78 & 1.93 \\
\hline JF-5 & 47.48 & 54.83 & 6.47 & 21.53 & 7.27 & 10.82 & 12.81 & 2.10 \\
\hline JF-6 & 47.02 & 55.67 & 5.97 & 24.87 & 6.30 & 9.30 & 11.11 & 2.27 \\
\hline JF-8 & 47.53 & 53.33 & 6.78 & 23.52 & 7.10 & 10.30 & 10.96 & 1.98 \\
\hline JF-9 & 46.73 & 55.67 & 5.97 & 27.23 & 7.38 & 8.78 & 11.72 & 2.82 \\
\hline JF-14 & 42.27 & 53.50 & 6.12 & 31.22 & 7.90 & 10.85 & 11.27 & 3.01 \\
\hline JF-15 & 47.50 & 55.83 & 6.62 & 31.73 & 8.00 & 11.58 & 10.92 & 3.21 \\
\hline JF-17 & 52.63 & 54.83 & 6.25 & 32.87 & 7.62 & 11.62 & 10.68 & 2.94 \\
\hline JF-18 & 43.78 & 55.83 & 6.48 & 28.45 & 7.48 & 12.17 & 11.06 & 2.53 \\
\hline JF-21 & 47.03 & 54.83 & 6.98 & 27.20 & 7.32 & 11.15 & 10.90 & 2.62 \\
\hline JF-22 & 39.33 & 52.33 & 4.80 & 23.63 & 8.85 & 11.62 & 11.18 & 2.35 \\
\hline UM-32 & 39.87 & 56.83 & 3.67 & 21.33 & 7.05 & 10.05 & 11.75 & 2.00 \\
\hline UM-34 & 40.80 & 56.33 & 4.75 & 20.80 & 6.48 & 8.57 & 10.43 & 1.81 \\
\hline UM-116 & 37.67 & 56.83 & 5.23 & 18.27 & 7.77 & 10.22 & 10.90 & 1.76 \\
\hline UM-117 & 36.93 & 56.33 & 4.02 & 17.47 & 7.00 & 10.00 & 11.70 & 1.83 \\
\hline UM-118 & 40.75 & 56.50 & 3.67 & 16.67 & 7.15 & 10.52 & 11.88 & 1.71 \\
\hline UM-127 & 33.68 & 55.50 & 4.47 & 19.78 & 6.47 & 9.12 & 11.73 & 1.76 \\
\hline UM-128 & 34.50 & 56.33 & 3.70 & 14.83 & 6.98 & 10.22 & 12.54 & 1.56 \\
\hline UM-129 & 35.68 & 55.00 & 4.97 & 15.48 & 6.90 & 9.48 & 11.72 & 1.75 \\
\hline UM-144 & 33.82 & 56.17 & 3.78 & 15.40 & 6.37 & 8.43 & 13.55 & 1.71 \\
\hline UM-301 & 38.83 & 55.50 & 4.73 & 17.27 & 6.72 & 8.92 & 12.52 & 1.83 \\
\hline UM-302 & 36.77 & 57.33 & 3.80 & 22.28 & 7.50 & 10.13 & 11.68 & 2.49 \\
\hline UM-304 & 38.97 & 56.50 & 4.60 & 16.98 & 7.08 & 11.52 & 11.22 & 1.53 \\
\hline RMT-1 & 39.13 & 56.67 & 4.42 & 21.60 & 5.82 & 6.83 & 11.89 & 1.75 \\
\hline Sonali & 32.67 & 56.17 & 3.33 & 22.30 & 6.90 & 10.03 & 10.93 & 1.72 \\
\hline IC-143823 & 40.58 & 74.00 & 11.10 & 26.67 & 7.72 & 13.22 & 8.35 & 2.31 \\
\hline IC-143867 & 35.47 & 74.00 & 11.37 & 31.23 & 6.23 & 10.03 & 6.72 & 1.90 \\
\hline IC-143875 & 36.48 & 74.50 & 11.53 & 29.65 & 6.82 & 11.42 & 7.65 & 1.91 \\
\hline Punjab-6 & 38.28 & 56.00 & 5.22 & 23.35 & 7.40 & 10.12 & 10.90 & 2.23 \\
\hline Kalmi & 43.52 & 55.83 & 5.80 & 26.50 & 7.48 & 9.28 & 10.89 & 2.21 \\
\hline Range & $32.67-52.63$ & $52.33-74.50$ & $3.33-11.53$ & $14.83-32.87$ & $6.23-8.85$ & $6.83-13.22$ & $6.72-13.55$ & $1.53-3.01$ \\
\hline Grand mean & 40.63 & 57.44 & 5.70 & 23.04 & 7.15 & 10.21 & 11.11 & 2.12 \\
\hline $\mathrm{CV}$ & 8.78 & 2.44 & 16.78 & 19.20 & 7.97 & 13.40 & 7.22 & 19.32 \\
\hline $\mathrm{CD}$ at $5 \%$ & 4.04 & 1.59 & 0.45 & 2.06 & 0.26 & 0.64 & 0.37 & 0.19 \\
\hline
\end{tabular}

tiple cropping programmes, if grown as seed spice.

Branches per plant: The range of variance for this character was 3.33 to 11.53 with a mean value of 5.70. The genotype Sonali had the minimum number of branches and the genotype IC-143875 had the maximum number of branches. The IC genotypes had profuse branching, almost twice the number of branches of JF series. Therefore, these geno- whereas JF -17 had the highest number of pod.

Pod length: Variability in pod length ranged from $5.83 \mathrm{~cm}$ to $8.85 \mathrm{~cm}$ with a mean value of $7.15 \mathrm{~cm}$. RMT-1 had the shortest pod length, while JF-22 had the longest pod length.

Seeds per pod: The range of variation for this character was 6.83 to 13.22 and the grand mean was 10.21. The genotypes RMT-1 and IC-143823 showed lowest number of seeds 
per pod and the highest number of seeds per pod, respectively.

Test weight: The range of variability observed in this character was $6.72 \mathrm{~g}$ in IC143867 to $13.55 \mathrm{~g}$ in UM-144 with a grand mean of $11.11 \mathrm{~g}$.

Seed yield per plant: The seed yield per plant varied from $1.53 \mathrm{~g}$ in UM-304 to $3.21 \mathrm{~g}$ in JF-15 with the grand mean of $2.12 \mathrm{~g}$. The genotypes JF-14, JF-15, JF-17, JF-18, JF21 showed seed yield significantly higher than $2.5 \mathrm{~g}$.

From the values of coefficient of variation, it was observed that the variability was highest in seed yield per plant followed by pods per plant, branches per plant and seeds per pod. Therefore, there is scope for selection of genotypes for combining desirable component characters in cross-breeding programme. Considerable amount of variability for pod and seed characters and seed yield per plant (Saha and Kole, 2001; Verma et al. 2003; Banerjee and Kole, 2004; Gangopadhyay et al. 2009; Prajapati et al., 2010, Ahari et al. 2011) has been reported earlier.

Considering the performance of the genotypes for important characters, including yield, the genotypes JF-14, JF-15, JF-17 and JF-21 could be considered for cultivation as seed spice of fenugreek in subhumid subtropical red lateritic belt of eastern India.

\section{REFERENCES}

Acharya S, Srichamroen A, Basu S, Ooraikul B and Basu T 2006 Improvement in the nutraceutical properties of fenugreek (Trigonella foenum-graecum L.). Songk. J. Sci. Tech. 28(1): 1-9.

Ahari DS, Hassandokht MR, Kashi AK, Amri A and Alizadeh KH 2010 Genetic variability of some agronomic traits in the Iranian fenugreek landraces under drought stress and non-stress condi- tions. Afr. J. Plant Sci. 4(2): 12-20.

Al-Habori M and Raman A 2002 Pharmacological properties in Fenugreek. In: Petropoulos GA (Ed) The genus Trigonella ( $1^{\text {st }}$ edition). Taylor and Francis, London and New York. Pp. 163-182.

Basch E, Ulbricht C, Kuo G, Szapary P and Smith M 2003 Therapeutic application of fenugreek. Alt. Med. Rev. 8: 20-27.

Banerjee, Ananya and Kole PC 2004 Genetic variability, correlation and path analysis in fenugreek (Trigonella foenumgraecum L.). J. Spices Aromatic Crops 13: 44-48.

Gangopadhyay KK, Yadav SK, Kumar G, Meena BL, Mahajan RK, Mishra SK and Sharma SK 2009 Correlation, path-coefficient and genetic diversity pattern in fenugreek (Trigonella foenum-graecum). Indian J. Agric. Sci. 79: 521-526.

Kole PC 2005 Stability analysis for seed yield and its component characters in fenugreek (Trigonella foenum-graecum L.). J. Spices Aromatic Crops 14: 4750.

Moyer JR, Acharya SN, Mir Z and Doram RC 2003 Weed management in irrigated fenugreek grown for forage in rotation with other annual crops. Can. J. Plant Sci. 83: 181-188.

Mathur VL, Ladu Lal and Lal L 1998 Stability of fenugreek (Trigonella foenumgraecum L.) varieties under saline conditions. Legume Res. 21: 3-4.

Prajapati DB, Ravindrababu Y and Prajapati BH 2010 Genetic variability and character association in fenugreek (Trigonella foenum-graecum L.). J. Spices Aromatic Crops 19: 61-64.

Rajagopalan MS 2001 Fenugreek: a savory medicinal. Suppl. Ind. Exec. 5(6): 4344.

Sharma RD 1990 Effect of fenugreek on blood glucose and serum lipids in type1 diabetes. Eur. J. Clin. Nutr. 44: 
301-306.

Saha A and Kole PC 2001 Genetic variability in fenugreek grown in sub-humid lateritic belt of West Bengal. Madras Agric. J. 88: 345-348.

Sharma RC, Godawat SL and Choudhury BR 1995 Stability analysis in fenugreek (Trigonella foenum-graecum L.). Indian J. Agric. Sci. 65: 834-835.

Verma Rakesh, Korla BN and Verma R 2003 Genetic variability in fenugreek (Trigonella foenum-graecum L.) grown under mid-hills of Himachal Pradesh. J. Spices Aromatic Crops 12: 60-62. 